\title{
INTERAKSI EDUKATIF ANTARA PENDIDIK DAN PESERTA DIDIK DALAM PENDIDIKAN ISLAM
}

\author{
Akhiril Pane \\ akhirilpane@gmail.com \\ IAIN Padang Sidempuan
}

\begin{abstract}
Abstrak
Interaksi edukatif adalah hubungan dua arah antara pendidik dan siswa dengan sejumlah norma sebagai media untuk mencapai tujuan pendidikan. Pendidik tidak hanya bertanggung jawab untuk menyampaikan materi pengajaran kepada siswa tetapi juga membentuk kepribadian siswa yang bernilai tinggi. Dalam pandangan modern, siswa tidak hanya dianggap sebagai objek atau sasaran pendidikan, tetapi juga harus diperlakukan sebagai mata pelajaran pendidikan. Karena keberhasilan atau kegagalan seorang pendidik dapat diukur dari aspek ini. Di sini pendidik adalah kunci untuk memegang kendali atas siswa. Artikel ini memiliki rumusan bagaimana gambaran komunikasi edukatif antara pendidik dan siswa dalam pendidikan Islam? Sedangkan tujuan penulisan artikel ini adalah untuk mendapatkan gambaran komunikasi pendidikan antara pendidik dan siswa dalam pendidikan Islam. Metode penulisan artikel ini adalah studi pustaka atau Library Research menggunakan teknik pengumpulan data yang diambil dari buku-buku ilmiah dan literatur yang relevan. Sedangkan teknik analisis data adalah Content Analysis, yaitu menganalisis data yang diperoleh dari buku atau literatur yang relevan. Kesimpulan dari penulisan artikel ini adalah bahwa dalam konsep pendidikan Islam komunikasi edukatif ditandai dengan adanya kecocokan antara nilai-nilai sebagai isi pesan dan dampak yang diinginkan oleh pendidik. Semakin tepat nilai yang diterima oleh siswa dan semakin jelas dampak yang diinginkan oleh pendidik, semakin efektif komunikasi pendidikan yang terjadi. Komunikasi edukatif yang berjalan secara efektif akan memungkinkan penyerapan makna pendidikan secara lebih penuh dan mendalam. Dengan demikian, komunikasi pendidikan adalah hal yang sangat penting dan signifikan dalam mendukung keberhasilan pembelajaran dalam pendidikan Islam.
\end{abstract}

\section{Kata kunci : Interaksi edukatif, Pendidik, Pendidikan Islam}

\begin{abstract}
Educative interaction is a two-way relationship between educators and students with a number of norms as a medium to achieve educational goals. Educators are not only responsible for delivering teaching material to students but also shape the personality of a high-value student. In the modern view, students are not only considered as objects or targets of education, but must also be treated as educational subjects. Because the success or failure of an educator can be measured from this aspect. Here educators are the key to holding control over students. This article has the formulation of how is the picture of educative communication between educators and students in Islamic education. While the purpose of writing this article is to get an overview of educational communication between educators and students in Islamic education. The method of writing this article is a library study or
\end{abstract}


Library Research using data collection techniques taken from relevant scientific books and literature. While the data analysis technique is Content Analysis, which is analyzing data obtained from relevant books or literature. The conclusion of the writing of this article is that in the concept of Islamic education educative communication is marked by the existence of a match between values as the message content and the impact desired by educators. The more appropriate the values received by students and the clearer the impact desired by the educator, the more effective the educational communication that occurs. Educative communication that runs effectively will allow the absorption of the meaning of education more fully and deeply. Thus, educational communication is a very important and significant thing in supporting the success of learning in Islamic education.

\section{Keywords: Educative Interaction, Educators, Islamic Education}

\section{Pendahuluan}

Manusia dalam kehidupannya akan bergantung pada orang lain dan tidak mungkin hidup sendirian, manakala dalam hidupnya akan terpenuhi secara baik. Dalam kehidupan sosial manusia pasti saling bergantung antara individu yang satu dengan individu lainnya. Sehingga manusia tidak bisa hidup sendirian dan pasti membutuhkan orang lain untuk mengatasi kendala yang ada dalam kehidupannya, dan juga manusia kapan dan di mana saja akan membutuhkan komunikasi dengan orang lain. Pada dasarnya setiap orang dapat berkomunikasi satu sama lainnya untuk memenuhi kebutuhannya. Namun tidak semua orang dapat secara trampil berkomunikasi secara efektif, oleh karena itu perlu dikenali berbagai cara/teknik penyampaian informasi. Komunikasi akan selalu menekankan pada penyampaian pesan dari seorang komunikator kepada seseorang sebagai penerima pesan.

Sehubungan dengan itu, teknik komunikasi dapat berfungsi untuk membentuk iklim organisasi yang menggambarkan suasana kerja antara guru dan siswa yang mampu menciptakan hubungan yang harmonis di antara keduanya. Guru harus peka dan tanggap terhadap gejolak dan fenomena yang terjadi pada diri siswa di lingkungan organisasi. Selain itu juga di antara guru dan siswa mampu berkomunikasi secara efektif dan terbuka, yang pada akhirnya dapat mengatasi segala problema pembelajaran di sekolah. Kondisi itu dapat menciptakan kemampuan dan meningkatkan kinerja guru untuk menjalankan tugasnya, sehingga dapat memberikan pelayanan kepada siswa semaksimal mungkin. Ini semua akan memberikan motivasi siswa untuk lebih semangat dalam 
belajar yang pada gilirannya siswa dapat meningkatkan prestasinya. Hal ini menunjukkan adanya teknik komunikasi yang baik antara guru dan siswa, dan juga berarti setiap guru dapat melaksanakan tugas, tanggungjawab, dan fungsinya sesuai dengan peraturan perundang-undangan yang berlaku sesuai dengan konsep pendidikan Islam.

\section{Pengertian Komunikasi Edukatif}

Secara etimologi, istilah komunikasi berasal dari bahasa Latin communicatio yang berasal dari kata communis yang berarti "sama", yang dimaksud dengan sama yaitu "sama makna". Sama makna yang dimaksud dalam hal ini yaitu, ketika komunikasi berlangsung antara komunikator dan komunikan memiliki kesamaan makna atas pesan atau informasi yang disampaikan. Bermacam-macam definisi tentang komunikasi banyak dikemukakan oleh para ahli komunikasi. Para ahli komunikasi tersebut bermaksud untuk memberikan batasan terhadap definisi dari komunikasi.

1. Definisi komunikasi menurut Agus M. Hardjana dalam Ngainun Naim, yaitu: ${ }^{1}$

Kata "komunikasi" berasal dari kata Latin cum, yaitu kata depan yang berarti dengan dan bersama dengan, dan unus, yaitu kata bilangan yang berarti satu. Dari kedua kata tersebut terbentuk sebuah kata benda communio yang dalam bahasa Inggris menjadi communion dan berarti kebersamaan, persatuan, persekutuan, gabungan, pergaulan dan hubungan. Dari kata ters23ebut dapat dibentuk sebuah kata kerja communicare yang berarti membagi sesuatu dengan seseorang, memberikan sebagian kepada seseorang, tukar-menukar, membicarakan sesuatu dengan seseorang, memberitahukan sesuatu kepada orang lain, bercakap-cakap, bertukar pikiran, berhubungan dan berteman. Dalam sudut pandang kesamaan pertukaran makna, komunikasi dapat didefinisikan sebagai proses penyampaian makna dalam bentuk gagasan atau informasi dari seseorang kepada orang lain melalui media tertentu.

Kesamaan makna merupakan hal terpenting sebagai inti dari proses komunikasi tersebut. Seorang komunikan diharapkan untuk mampu memberikan respon atau feedback dari pesan atau informasiyang disampaikan ketika proses komunikasi berlangsung. Respon atau feedback yang diberikan tersebut yaitu berkaitan dengan arti atau makna yang disampaikan dalam pesan. Pengertian komunikasi menurut Suranto AW: "Komunikasi adalah suatu proses pengiriman

\footnotetext{
${ }^{1}$ Ngainun Naim. Dasar-dasar Komunikasi Pendidikan.( Yogyakarta: ArRuzz Medi, 2011), hlm. 17
} 
pesan atau simbol-simbol yang mengandung arti dari seorang komunikator kepada komunikan dengan tujuan tertentu". Dalam komunikasi terdapat suatu proses dan simbol-simbol yang mengandung arti. Arti atau makna dari simbol disini tergantung pada pemahaman dan persepsi komunikan. ${ }^{2}$

2. Selanjtnya, menurut Brantas komunikasi secara umum dapat diartikan sebagai "Proses penyampaian informasi dari komunikator kepada komunikan dengan menggunakan media. Sehingga informasi dapat dipahami oleh kedua belah pihak, serta saling memiliki kesamaan arti lewat transmisi pesan secara simbolik". ${ }^{3}$

3. Kenneth N. Wexley \& Gary A. Yuki yang diterjemahkan oleh Muh. Shobaruddin sebagai berikut:

Komunikasi merupakan penyampaian informasi antara dua orang atau lebih. Komunikasi merupakan suatu proses yang vital dalam organisasi karena komunikasi diperlukan bagi efektivitas kepemimpinan, perencanaan, pengendalian, koordinasi, latihan, manajemen konflik, serta proses-proses yang lain. ${ }^{4}$

4. Forsdale menyatakan bahwa "Communication is the process by the which a system is estabilished, maintained, and altered by means of shared signals thet operate according to rules."

5. Arni Muhammad mengemukakan komunikasi sebagai bertukarnya pesan verbal maupun nonverbal dikirimkan, diterima dan diberi arti. ${ }^{5}$

6. Hovland, Janis dan Kelley menyatakan bahwa "Communication is the process by which an individual transmits stimulty (usually verbal) to modify the behavior of other individuals."

7. Miftah Toha menyatakan bahwa komunikasi merupakan suatu proses untuk menyampaikan dan menerima berita atau informasi dari seseorang ke orang lain. ${ }^{6}$

2 Suranto AW, Komunikasi Perkantoran (Prinsip Komunikasi Untuk Meningkatkan Kinerja Karyawan). (Yogyakarta: Media Wacana, 2005), hlm. 11

${ }^{3}$ Brantas. Dasar-dasar Manajemen (Bandung: Alfabeta, 2009), hlm. 160

${ }^{4}$ Wexley N., Kenneth \& Gary A. Yuki diterjemahkan oleh Muh. Shobaruddin, Perilaku Organisasi dan Psikologi Personalia (Jakarta: PT Rineka Cipta, 2003), hlm. 70.

${ }^{5}$ Muhammad Arni, Komunikasi Organisasi, Cet 8 (Jakarta: Bumi Aksara, 2007), hlm. 2-4

${ }^{6}$ Thoha Miftah, Perilaku Organisasi Konsep Dasar dan Aplikasinya (Jakarta: Raja Grafindo Persada, 2009), hlm.167. 
8. Dalam bahasa Arab kounikasi merupakan "Muwaasholat" (Al-Kalali, 1997: 276) sehinngga komunikasi berhubuingan erat dengan shalat yang mempunyai arti ibadah kepada Allah SWT dan shilah yang mempunyai arti menyambung. Komunikasi dalam Islam ada dua yaitu komunikasi vertikal dan horisontal. Komunikasi vertikal terjadi antara manusia dengan Allah SWT sementara komunikasi horisontal terjadi antara sesama manusia atau yang biasa disebut Muamalah. ${ }^{7}$

9. Komunikasi dalam lingkup dunia pendidikan selanjutnya dapat pula diartikan menyampaikan pesan dari pendidik kepada peserta didik. Penyampaian pesan ini memiliki banyak tujuan misalnya, mengubah tingkah laku peserta didik atau orangorang yang terlibat dalam komunikasi ini. Sehingga dapat pula diartikan jika pendidik ialah bapak rohani bagi peserta didik sehingga komunikasi antara keduanya harus berjalan.

Berdasarkan beberapa definisi mengenai komunikasi tersebut, dapat disimpulkan bahwa komunikasi merupakan proses pengirima pesan oleh komunikator yang kemudian diterima da diinterpretasikan oleh komunikan, dengan tujuan untuk mencapa kesamaan pandangan atas pesan yang dikomunikasikan. Sebaga suatu proses penyampaian informasi, individu yang terlibat dalam kegiatan komunikasi, khususnya komunikator perlu merancang menyajikan informasi yang benar an tepat sesuai setting komunikasi, dan informasi tersebut disajikan dengan menggunakan bahasa yang sesuai dengan situasi komunikasi dan tingkat nalar penerimaan lawan komunikasi. Setelah pesan yang disampaikan komunikator dapat diterima dan dipahami oleh komunikan sesuai dengan maksud pesan yang sesungguhnya, diharapkan adanya suatu perubahan dari komunikan sebagai efek yang terjadi pada diri komunikan, ataupun umpan balik yang diberikan kepada komuniktor berupa saran atau tanggapan. Secara sederhana, kegiatan komunikasi dipahami sebagai kegiatan penyampaian dan penerimaan pesan atau ide dari satu pihak ke pihak lain.

Sementara itu pengertian Komunikasi Edukatif merupakan komunikasi yang dilakukan oleh dua orang atau lebih yang bersifat mendidik. Dalam dunia pendidikan,

\footnotetext{
${ }^{7}$ Siti Aminah, "Membangun Komunikasi Efektif antara Pendidik dengan Peserta Didik dalam Perspektif Islam”, Madrasah, Vol. 5, No.2, Januari-Juni 2013, hlm. 140.
} 
segala aspek kegiatan khususnya di sekolah keberadaan komunikasi menjadi hal pokok dalam berjalannya seluruh kegiatan pembelajaran. Komunikasi pendidikan akan mampu menunjukkan arah proses pendidikan itu sendiri. Suryosubroto B. menyebut komunikasi eduktif ini dengan istilah interaksi edukatif.

Menurut Suryosubroto B. "interaksi edukatif adalah hubungan timbal balik antara guru (pendidik) dan peserta didik (murid), dalam suatu sistem pengajaran". ${ }^{8}$ Komunikasi edukatif merupakan hal penting dalam kegiatan belajar mengajar demi terwujudnya situasi pembelajaran yang baik. Melalui komunikasi edukatif antara guru dan peserta didik yang berjalan dengan baik, maka tujuan proses belajar mengajar dapat tercapai. Pawit M. Yusuf menjelaskan definisi komunikasi yaitu, "Komunikasi pendidikan adalah komunikasi yang merambah atau menyentuh dunia pendidikan". 9 Komunikasi pendidikan dirancang secara khusus untuk meningkatkan nilai tambah bagi para peserta didik dalam berbagai bidang kehidupan.

Komunikasi yang berlangsung dalam dunia pendidikan harus mampu mendidik dan membimbing peserta didik serta bersifat edukatif. Selain itu definisi komunikasi atau interaksi edukatif menurut Winarno Surakhmad, yaitu "Interaksi yang terjadi dalam situasi edukatif, yakni interaksi yang berlangsung dalam ikatan tujuan pendidikan". Difinisi komunikasi edukatif atau interaksi edukatif menurut Syaiful Bahri Djamarah, yaitu " hubungan dua arah antara guru dan anak didik dengan sejumlah norma sebagai mediumnya untuk mencapai tujuan pendidikan". ${ }^{10}$ Selanjutnya, menurut Ngainun Naim, "komunikasi pendidikan dapat diartikan sebagai komunikasi yang terjadi dalam suasana pendidikan.

Dengan demikian, komunikasi pendidikan adalah proses perjalanan pesan atau informasi yang merambah bidang atau peristiwa-peristiwa pendidikan". ${ }^{11}$ Sehingga kegiatan komunikasi dalam dunia pendidikandikendalikan dan dikondisikan untuk mencapai tujuan-tujuan pendidikan. Proses pembelajaran pada hakikatnya merupakan

\footnotetext{
${ }^{8}$ Suryosubroto B., Proses Belajar Mengajar Di Sekolah. (Jakarta: PT Rineka Cipta, 2002), hlm. 156

${ }^{9}$ Pawit M. Yusuf, Komunikasi Instruksional, Teori dan Praktik, (Jakarta: Bumi Aksara, 2010), hlm.2

${ }^{10}$ Syaiful Bahri Djamarah, Guru dan Anak Didik dalam Interaksi Edukatif. (Jakarta: PT Rineka Cipta, 2005)hlm. 11.

${ }^{11}$ Ngainun Naim, Op. Cit., hlm. 27.
} 
suatu proses komunikasi, yaitu penyampaian pesan dari komunikator kepada komunikan. Pesan yang disampaikan dalam komunikasi edukatif yaitu berupa isi atau ajaran atau nilai-nilai dan budaya yang dituangkan dalam proses pembelajaran antara guru dan peserta didik.

\section{Pengertian Pendidik}

Dalam dunia pendidikan ada yang disebut dengan guru yang lazim juga disebut sebagai pendidik. Menurut Triyo Supriyatno istilah guru adalah orang yang kerjanya mengajar/memberikan pelajaran di sekolah atau di kelas. Secara lebih khusus lagi, bahwa guru agama Islam merupakan orang yang bekerjanya di bidang pendidikan dan pengajaran, yang ikut bertanggungjawab dalam membantu anak dalam mencapai kedewasaan masing-masing peserta didik. ${ }^{12}$

Pendidik adalah orang yang utama dan pertama melakukan kegiatan dalam bidang mendidik yaitu mentransfer ilmu pengetahuan pada siswa atau peserta didik. Kunandar menjelaskan guru merupakan salah satu ujung tombak yang menjadi tumpuan, harapan, dan andalan masyarakat bangsa, guru merupakan keberhasilan masyarakat bangsa dan Negara secara keseluruhan, begitu juga sebaliknya kegagalan guru adalah kegagalan semua. Hal ini membuktikan bahwa kunci keberhasilan pendidikan berada ditangan guru itu sendiri. ${ }^{13}$

Sementara Muhammad Nurdin menjelaskan guru adalah orang yang bertanggungjawab terhadap perkembangan anak didik dengan mengupayakan seluruh potensinya, baik potensi kognitif, afektif, dan psikomotorik. Selain itu juga guru bertanggungjawab dalam memberikan pertolongan pada anak didik dalam perkembangan jasmani dan rohaninya agar mencapai kedewasaan, serta mampu dalam memenuhi tugasnya sebagai hamba Allah SWT. ${ }^{14}$

Pengertian pendidik secara etimologi adalah orang yang mendidik. Dalam konteks pendidikan Islam, pendidik disebut dengan berbagai istilah, diantaranya sebutan

12 Triyo Supriyatno, Paradigma Pendidikan Islam Berbasis Teo - Antropo Sosiosentris, (Malang: Universitas Islam Negeri Malang, 2004), hlm. 17.

${ }^{13}$ Kunandar, Guru Profesional, (Jakarta: PT Raja Grafindo Persada, 2007 ), hlm. 37.

${ }^{14}$ Muhammad Nurdin, Kiat Menjadi Guru Profesional, (Jogjakarta: Ar-Ruzz Media, 2007), hlm. 127128. 
Ustadz, Mua'allim, Murabbi, Mursyiddan Mudarris. Ustadz adalah orang yang berkomitmen dengan profesionalitas, yang melekat pada dirinya sikap dedaktif, komitmen terhadap mutu proses dan hasil kerja. Mu'allim adalah orang yang menguasai ilmu dan mampu mengembangkannya serta menjelaskan fungsinya dalam kehidupan. Murabbi adalah orang yang mendidik dan menyiapkan peserta agar mampu berkreasi serta mampu mengatur dan memelihara hasilk reasinya untuk tidak menimbulkan malapetaka bagidirinya, masyarakat, dan alam sekitarnya.

Mursyid adalah orang yang mampu menjadi model atau sentral identitas diri atau menjadi pusat anutan, teladan, dan konsultan bagi peserta didik. Dan Mudarris adalah orang yang mampu menyiapkan peserta didik untuk bertanggung jawab dalam membangun peradabanyang berkualitas di masa depan. ${ }^{15}$ Perbedaan-perbedaan istilah itu merupakan bentuk adaptif kata "pendidik" terhadap konteks dimana dan dalam kondisi bagaimana kata tersebut digunakan. Dari istilah istilah pendidikan dalam konteks pendidikan Islam di atas, kata "pendidik" sejatinya secara fungsional menunjukkan kepada seseorang yang melakukan kegiatan dalammemberikan pengetahuan, keterampilan, pendidikan, pengalaman, dan apasaja yang bermanfaat dalam kehidupan. Orang yang melakukan kegiatanini bisa siapa saja dan dimana saja. ${ }^{16}$ Kegiatan mendidik yang dilakukan pendidik tersebut secara umum dilakukan di tiga tempat atau yang seringkita sebut dengan tri pusat pendidikan, yaitu pendidikan dalam keluarga (informal), pendidikan di masyarakat (non formal) danpendidikn di sekolah (formal).

Selanjutnya pengertian pendidik secara terminologi,para pakar pendidikan Islam menggunakan rumusan yang berbeda-beda. Berikut akan dijelaskan beberapa pendapat para ahli, diantaranya:

1. Zakiah Darajat berpendapat bahwa pendidik adalah individu yang akanmemenuhi kebutuhan pengetahuan, sikap dan tingkah laku peserta didik,sementara Ahamad D Marimba mengartikan sebagai orang yang memikul peretanggungjawaban sebagai

\footnotetext{
${ }^{15}$ Purwadarminto,Kamus umum Bahasa Indonesia (Jakarta: Balai Pustaka, 1991) hlm. 250

${ }^{16}$ Basuki \& MiftahulUlum, Pengantar Ilmu Pendidikan Islam, (Ponorogo: STAIN PO Pres, 2007),
} hlm. 78 
pendidik,yaitu manusia dewasa yang karena hak dan kewajibannya bertanggung jawab tentang pendidikan peserta didik.

2. Dalam UU No. 20 tahun 2003, pendidik adalah tenaga pendidikan yang berkualifikasi sebagai guru, dosen, konselor, pamong belajar, widyaswara, tutor instruktur, fasilitator dan sebutan lain yang berpartisipasi dalam menyelenggarakan pendidikan. Pendidik merupakan tenaga professional yang bertugas merencanakan dan melaksanakan proses pembelajaran, menilai hasil pembelajaran, melakukan pembimbingan dan pelatihan, serta melakukan penelitian dan pengabdian kepada masyarakat, terutama bagi pendidik pada perguruan tinggi. Dalam hal ini pendidik (guru) adalah seorang yang memberikan Pengetahuan, ketrampilan di sekolah dan secara lebih khusus lagi, bahwa pendidik (guru) berarti orang yang bekerja dalam bidang pendidikan dan pengajaran yang ikut bertanggungjawab dalam membantu anak dalam mencapai kedewasaannya.

Pekerjaan guru adalah membina dan mendidik seluruh kemampuan sikap dan prilaku yang baik peserta didik. Membina dan mendidik perkembangan sikap dan kepribadian peserta didik tidak terbatas pelaksanaannya melalui pembinaan di dalam kelas. Untuk melaksanakan tugas tersebut seorang guru harus mengikuti ketentuan persyaratan pendidik yaitu:

1. Pendidik harus memiliki kualifikasi minimum dan sertifikasi sesuai dengan jenjang kewenangan mengajar, sehat jasmani, dan rohani, serta memiliki kemampuan untuk mewujudkan tujuan pendidikan nasional.

2. Pendidik untuk pendidikan formal pada jenjang pendidikan usia dini, pendidikan dasar, pendidikan menengah, pendidikan tinggi dihasilakn oleh perguruan tinggi yang terakreditasi.

3. Ketentuan mengenai kualifikasi pendidik sebagaimana dimaksud dalam ayat 1 dan 2 diatur lebih lanjut dengan peraturan pemerintah. ${ }^{17}$

Melalui persyaratan guru di atas, seorang guru diharapkan dapat melaksanakan tugas dan fungsinya secara baik dan maksimal. Adapun tugas dan fungsi guru meliputi:

${ }^{17}$ E. Mulyasa, Menjadi Guru Profesional Menciptakan Pembelajaran Kreatif dan Menyenangkan, (Bandung: PT. Rosyda Karya, 2007), hlm. 198. 
pertama, tugas pengajaran atau sebagai pengajar; kedua, tugas bimbingan dan penyuluhan atau guru sebagai pembimbing dan pemberi bimbingan; dan ketiga, tugas administrasi atau guru sebagai pemimpin (menejer kelas). ${ }^{18}$

\section{Pengertian Peserta Didik}

Dalam pendidikan Islam peserta didik merupakan individu yang sedang tumbuh berkembang, baik secara fisik, psikis, sosial dan secara rohaninya dalam menjalankan kehidupan di dunia maupun akhirat. Sehingga peserta didik merupakan individu yang belum dewasa dan membutuhkan bantuan orang lain untuk membuatnya tumbuh dewasa. Peserta didik yang dimaksud ialah manusia yang berada pada masa pertumbuhan dan perkembangan. Seabrek kebutuhan yang sudah disebutkan diatas ada dua kebutuhan yang harus terpenuhi agar seorang anak atau peserta didik dapat mengembangkan bakat dalam dirinya. Dua kebutuhan ini adalah kebutuhan fisik dan nonfisik. Dalam kehidupan yang sesungguhnya dua kebutuhan ini sulit dilihat batas antara keduanya sehingga ada keterkaitan yang saling mengisi. Misalnya karena korelasi keduanya yang erat maka komunikasi sangat dibutuhkan demi terpenuhi dua kebutuhan ini. Komunikasi ini dimulai dari kepekaan indra, pikiran, dan ketrampilan untuk dapat melakukan sesuatu yang mendorongnya berpikir secara individu. Demikian sehingga tingkat keberhasilan paling tinggi yang dapat diraih pendidik adalah ketika peserta didik mampu menuntun diri mereka sendiri menjadi pendidik diri sendiri.

Dalam surah Al-Baqarah ayat 30-34 dijelaskan tentang komunikasi antara Allah SWT dengan malaikatnya, Iblis dan Adam. Dalam percakapan itu Allah SWT menunjukkan jika dirinya adalah sang Maha Pendidik dan peserta didiknya adalah ketiga makhluk itu. Ketiga makhluk itu diciptakan dengan karakter yang berbedabeda. Di mana malaikat merupakan peserta didik yang selalu taat kepada Allah SWT, sedang Iblis mempunyai ciri yang selalu membangkang, dan Adam mempunyai sikap taat dan membangkang. Adam sebagai wakil dari manusia jika memiliki sikap yang taat berarti

${ }^{18}$ Zakiah Deradjat, Metodik Khusus Pengajaran Agama Islam, (Jakarta: Bumi Aksara, 2004), hlm. 264-265. 
dia mendapatkan derajat lebih tinggi dari malaikat. Sementara manusia yang mempunyai sikap pembangkang seperti iblis maka derajatnya lebih rendah dari hewan. ${ }^{19}$

Urusan pendidikan anak atau peserta didik ini juga diatur dalam Islam. Sebagaimana kita ketahui bahwa pendidikan merupakan fitrah manusia yang harus didapatkan. Sehingga Islam sangat menganjurkan seorang anak atau peserta didik untuk menuntut ilmu. Dalam konsep fitrah ini terdapat beberapa hal potensial yang siap dikembangkan dan dimiliki seorang anak atau peserta didik. Adapun hal itu antara lain adalah sebagai berikut:

1. Kemampuan dasar dominan yang dimiliki setiap anak, di mana kemampuan ini setiap anak tidaklah sama.

2. Secara naluriah setiap anak akan mempunyai kecenderungan yang berbeda.

3. Kemampuan dasar mempercayai Tuhan dan beragama secara umum.

4. Terdapat pula komponen psikologis seperti bakat, nafsu, karakter, perasaan, juga intuisi yang dapat terlihat. ${ }^{20}$

Selain itu kecerdasan seorang anak atau peserta didik juga terbagi menjadi beberapa bagian. Ramayualis mengemukakan pendapatnya tentang kecerdasan anak, dia membagi kecerdasan ini menjadi beberapa hal meliputi, kecerdasan intelektual, kecerdasan emosional, kecerdasan spiritual, dan kecerdasan qalbu atau hati. Kecerdasan intelektual sendiri merupakan kecerdasan. Selain itu kecerdasan seorang anak atau peserta didik juga terbagi menjadi beberapa bagian.

Ramayulis mengemukakan pendapatnya tentang kecerdasan anak, dia membagi kecerdasan ini menjadi beberapa hal meliputi, kecerdasan intelektual, kecerdasan emosional, kecerdasan spiritual, dan kecerdasan qalbu atau hati. Kecerdasan intelektual sendiri merupakan kecerdasan yang menuntut pemberdayaan otak, hati, jasmani dan pengaktifan manusia untuk berinteraksi. Kecerdasan emosional merupakan kemampuan untuk memotivasi diri sendiri sehingga mampu menghadapi frustasi dan mampu mengendalikan dorongan hati. Selanjutnya kecerdasan spiritual adalah kemampuan

19 Abdul Mujib dan Jusuf Mudzakir, Nuansa-Nuansa Psikologi Islam, (Jakarta: PT Raja Grafindo Persada, , 2001), hlm. 91.

20 Ibid. 
dalam memberi makna dari setiap ibadah kepada perilaku serta kegiatan sehari-hari. Seorang panak atau peserta didik juga dapat dipantau melalui terpenuhinya kebutuhan lainnya..

Dalam UU sisdiknas 2003 pasal 1 ayat 4, di jelaskan bahwa yang disebut peserta didik adalah anggota masyarakat yang berusaha mengembangkan potensi diri melalui proses pembelajaran yang tersedia pada jalur, jenjang, dan jenis pendidikan tertentu. ${ }^{21}$ Dalam perspektif pendidikan Islam peserta didik merupakan subjek dan objek. Oleh karena itu proses kependidikan tidak akan terlaksana tanpa keterlibatan pesera didik, di dalamnya. Dalam paradigma pendidikan Islam, peserta didik merupakan orang yang belum dewasa yang memiliki sejumlah potensi (kemampuan) dasar yang masih perlu dikembangkan.

Dalam paradigma pendidikan Islam, peserta didik merupakan orang yang belum dewasa yang memiliki sejumlah potensi (kemampuan) dasar yang masih perlu dikembangkan. Di sini, peserta didik merupakan makhluk Allah yang memiliki fitrah jasmani maupun rohani yang belum mencapai taraf kematangan baik bentuk, ukuran maupun perimbangan pada bagian-bagian lainnya. Dari segi rohaniah ia memiliki bakat, memiliki kehendak, perassaan dan pikiran yang dinamis dan perlu dikembangkan. Secara kodrati, anak memerlukan pendidikan atau bimbingan dari orang dewasa. Dasar kodrati ini dapat dimengerti dari kebutuhan-kebutuhan dasar yang didmiliki anak yang hidup didunia ini. Sebagaimana Hadis Nabi, yang artinya " tidaklah seseorang yang dilahirkan melainkan menurut fitrahnya, maka kedua orang tuanyalah yang meYahudikannya atau me-Nasranikannya atau me-Majusikannya. ${ }^{22}$

Orang tua sangat menetukan dalam mengarahkan dibawah kemana pendidikan anak atau masa depannya,dalam prosesnya selanjutnya kemampuan dari sesorang akan menambah keberhasilan dalam meraih sesuatu yang diinginkan. Ibarat sebuah tanaman tergantung orang yang menanam kemudian merawat tanaman tersebut maka di kemudian hari tanaman tersebut akan berbuah. Disamping itu dalam Al-Qur'an Surat

${ }^{21}$ Undang-Undang Sisdiknas (Sistim Pendidikan Nasional) Tahun 2003

22 Himpunan Khutbah Pembangunan satu tahun, Direktorat Penerangan agama Islam Tahun 1991/1992, hlm. 208 
an-Nahl ayat 78 juga dijelaskan: "Dan Allah mengeluarkan kamu dari perut ibumu dalam keadaan tidakmengetahui sesuatupun, dan dia memberi kamu pendengaran, penglihatan danhati, agar kamu bersyukur.” (QS.an-Nahl: 78).

Dari hadis dan ayat di atas dapat patut diperhatikan bahwa untuk menentukan status manusia sebagaimana mestinya adalah melalui proses pendidikan. Agar pelaksanaan proses pendidikan Islam dapat mencapai tujuan yang diinginkannya, maka setiap peserta didik hendaknya senantiasa menyadari tugas dan kewajibannya. Dalam perspektif Islam, anak didik sejak lahir sudah dianjurkan untuk dirangsang dengan suarasuara seperti suara adzan, iqamah, pepujian, suara bacaan ayat-ayat suci Al-Qur'an, lagulagu Islami dan lain sebagainya.

Spirit dari ayat tersebut adalah pendidikan saling keterkaitan antar pendidik dengan peserta didik, terutama dalam memberi nilai-nilai pendidikan awal perlu dirangsang atau dipancing dengan suara-suara spiritual.

\section{Metode dan Analisis Data}

Penulisan artikel ini menggunakan jenis penelitian library research (penelitian kepustakaan), yaitu penelitian yang dilaksanakan dengan menggunakan literatur (kepustakaan), baik berupa buku, catatan, maupun laporan hasil penelitian dari penelitian terdahulu. ${ }^{23}$ Sebagaimana menurut pemikiran M. Iqbal Hasan, studi dokumentasi adalah teknik pengumpulan data yang tidak langsung diajukan pada sebuah penelitian, namun melalui dokumen. Sementara teknik pengumpulan data penulis melakukan identifikasi wacana dari buku-buku yang relevan dengan judul penulisan artikel ini. Kemudian analisis data yang digunakan dalam penulisan artikel ini menggunakan metode analisis deskriptif dan analisis isi (content analisys). Metode analisis deskriptif yaitu adalah data yang dikumpulkan berupa kata-kata, gambar dan bukan angka-angka. Begitupun analisis isi yaitu dengan menganalisis setiap kata-kata, konsep ataupun pemikiran dalam buku-buku tersebut.

\section{Temuan Hasil Pembahasan}

\section{Komunikasi Edukatif antara Pendidik dan Peserta Didik dalam Pendidikan Islam}

${ }^{23}$ M. Iqbal Hasan, Pokok-pokok Materi Metodologi Penelitian dan Aplikasinya, (Jakarta: Ghalia Indonesia, 2002), hlm, 11. 
Pendidikan tidak akan pernah bisa sampai kepada tujuan yang di targetkan apabila salah satu dari dua unsur utama pendidik dan peserta didik nya tidak berkomunikasi secara sinergis dalam pembelajaran. Kedua unsur tersebut adalah pendidik dan peserta didik. Oleh sebab itu, perlu menjalin hubungan yang harmonis antara pendidik dan peserta didik bahkan menurut Hasan al Banna, hubungan antara pendidik dan peserta didik itu seharusnya bagaikan orang tua dan anak yang memiliki kedekatan secara emosional. Peserta didik biasanya akan lebih mudah menerima pelajaran kalau mereka dikondisikan dalam situasi nyaman dan merasa dihargai layaknya rumah sendiri. Pendidik harus fleksibel dalam pendekatan dengan peserta dalam hal pembelajaran juga harus bisa membuat mereka tetap bersikap santun.

Pola interaksi pendidik dan peserta didik untuk mencapai interaksi dalam pembelajaran dibutuhkan komunikasi edukatif antara pendidik dan peserta didik, yang memadukan dua kegiatan, yaitu kegiatan mengajar (usaha pendidik) dan kegiatan belajar (tugas peserta didik). Pendidik perlu mengembangkan komunikasi secara efektif dalam proses pembelajaran. Ada tiga pola komunikasi dalam proses balajar mengajar, antara lain sebagai berikut :

1. Komunikasi sebagai aksi atau komunikasi satu arah

Dalam komunikasi ini pendidik berperan sebagai pemberi aksi dan peserta didik sebagai penerima aksi. Pendidik aktif, peserta didik pasif.

2. Komunikasi sebagai interaksi atau komunikasi dua arah

Pada komunikasi ini antara pendidik dan peserta didik memiliki peranan yang sama yakni pemberi aksi dan penerima aksi dengan aksi keduanya dengan saling member dan saling menerima.

3. Komunikasi sebagai interaksi atau komunikasi banyak arah.

Komunikasi ini tidak hanya melibatkan interaksi yang dinamis antara pendidik dan peserta didik , tetapi juga melibatkan interaksi dinamis antara peserta didik dengan peserta didik lainnya.

Pendidikan sering dimaknai sebagai suatu bentuk transmisi nilai atau budaya dari guru (pendidik) kepada peserta didik (terdidik) atau dari orang tua kepada anak-anaknya. Pendidikan sebagai suatu upaya transmisi nilai dari seseorang kepada orang lain. Proses 
transmisi nilai tersebut terjadi melalui komunikasi antara pendidik (guru) dan peserta didik atau antara orang tua dan anak-anaknya. Komunikasi yang terjadi dalam rangka transmisi nilai ini sesungguhnya merupakan suatu komunikasi edukatif. Tidak semua bentuk komunikasi merupakan komunikasi edukatif atau komunikasi pendidikan. Aspek yang paling substansial dalam komunikasi pendidikan yaitu terjadinya transmisi nilai. Selama kegiatan belajar mengajar guru tidak akan pernah terlepas dari proses komunikasi. Komunikasi yang terjadi tersebut diharapkan tidak hanya sebatas proses penyampaian materi pelajaran saja, melainkan juga adanya proses transmisi nilai. Ketika proses kegiatan belajar mengajar, penerapan komunikasi edukatif menjadi penting dan memegang peran yang signifikan guna tercapainya tujuan pembelajaran. Nilai-nilai yang disampaikan oleh seorang pendidik merupakan salah satu dari komponen komunikasi, yaitu merupakan komponen pesan.

Efektivitas komunikasi edukatif ditandai oleh adanya kesesuaian antara nilainilai sebagai isi pesan dan dampak yang diinginkan oleh pendidik. Semakin sesuai nilai nilai yang diterima oleh peserta didik dan semakin jelas dampak yang diinginkan oleh pendidik, maka semakin efektif komunikasi edukatif yang terjadi. Komunikasi edukatif yang berjalan secara efektif akan memungkinkan terserapnya makna pendidikan secara lebih utuh dan mendalam. Dengan demikian, komunikasi edukatif merupakan suatu hal yang sangat penting dan signifikan dalam menunjang keberhasilan pembelajaran.

Secara khusus ada beberapa macam komunikasi dalam dunia pendidikan di antaranya:

1. Komunikasi Pribadi

Komunikasi pribadi merupakan proses bertukarnya informasi antara seorang dengan seorang lainnya. Komunikasi ini terjadi dengan tatap muka sehingga langsung dari penutur satu terhadap lawan bicaranya. Sedangkan dalam lingkup sekolah komunikasi pribadi ini sangat sering terjadi. Misalnya komunikasi antar peserta didik, komunikasi peserta didik dengan pendidik, juga antar pendidik dan lain sebagainya.

2. Komunikasi Kelompok Kecil 
Komunikasi kelompok kecil ini merupakan komunikasi yang biasanya terjadi dalam suatu kelompok kecil. Misalnya komunikasi yang terjadi dalam diskusi-diskusi kecil atau timtim kecil. Dalam lembaga pendidikan biasanya ini terjadi antar kelompok guru mata pelajaran yang sama atau terjadi antar peserta didik yang sedang belajar kelompok.

3. Komunikasi Publik

Komunikasi publik merupakan komunikasi yang lebih luas dari komunikasi kelompok kecil. Komunikasi ini biasanya melibatkan beberapa organinasi sehingga pesan atau berita itu dikomunikasikan dengan orang-orang diluar organisasi atau komunitasnya. Komunikasi ini bisa terjadi melalui tatap muka langsung maupun dengan media lainnya, misalnya surat elektronik, gawai, maupun telepon seluler. Sedangkan dalam lingkup sekolah komunikasi ini biasanya terjadi antara lembaga dengan orangtua wali peserta didik. Di mana mereka merupakan kelompok lain yang berada diluar lingkarang lembaga sekolah tersebut. Selain itu komunikasi ini juga terjadi ketika sekolah membuat berita lantas diterbitkan dan disebarluaskan kepada orang banyak.

4. Komunikasi Horizontal atau Setara

Komunikasi jenis ini biasanya terjadi pada orang-orang yang mempunyai kedudukan setara. Misalnya dalam sekolah komunikasi ini terjadi antara sesama pendidik dan sebaliknya komunikasi yang terjadi antara sesama peserta didik juga merupakan komunikasi setara.

5. Komunikasi Vertikal

Komunikasi vertikal merupakan komunikasi yang biasanya dilakukan oleh orangorang yang memiliki kedudukan sosial tidak sama. Misalnya dalam suatu organisasi seorang anggota biasa bisa berkomunikasi dengan ketua organisasinya hal inilah yang disebut komunikasi vertikal. Komunikasi jenis ini merupakan instruktif di mana atasan kepada bawahan. Jika dianalogikan dalam sekolah maka bisa jadi ini komunikasi kepala sekolah kepada guru mata pelajaran. Contoh lain adalah komunikasi seorang pendidik kepada peserta didiknya. 
Begitupun halnya dengan model komunikasi adukatif dan efektif yang dapat dipakai pendidik dalam menyampaikan informasi atau pesan kepada pesera didiknya. Dalam Islam perkataan yang baik atau tutur kata yang sopan ini disebut Qoulan Sadidan. Qoulan Sadidan berarti ucapan atau pembicaraan yang benar baik dari segi isi maupun tata bahasa. Berdasarkan substansinya seorang pendidik harus menyampaikan informasi yang benar, faktual, serta tidak menyembunyikan fakta. Sedangkan makna Sadidan tidak berarti benar namun juga harus tepat sasaran.

Dalam artian pendidik juga harus melihat dengan siapa dirinya berdialog. Pendidik harus bisa membedakan dialog yang dilakukan dengan sesama pendidik akan berbeda dan mesti berbeda dengan peserta didik. Demikian ucapan tersebut harus benar sehingga dapat tercapai apa yang ingin disampaikan pendidik kepada peserta didiknya. Kata-kata yang diucapkan pun harus lemah lembut. Jika mengkritik pun juga harus dibarengi upaya untuk memperbaiki. Selanjutnya untuk menghindari distorsi dalam komunikasi misalnya salah pengucapan atau penyampaian oleh pendidik telah dicontohkan dalam Islam. Nabi SAW pernah bicara kepada Aisyah dan kemudian diceritakan kembali oleh Aisyah. Aisyah menceritakan bahwa, "Rasulullah tidaklah berbicara seperti yang biasa kamu lakukan (yaitu berbicara dengan nada cepat). Namun berfungsi agar timbal balik yang baik ini berulang. Pengulangan positif ini merupakan tanda bahwa umpan yang diberikan pendidik dapat mempengaruhi kondisi mental peserta didik dengan baik. Setelah timbal balik yang diberikan oleh peserta didik positif, maka pendidik dapat memberikan penghargaan terhadap mereka.

Hal inilah yang terkadang dilupakan oleh pendidik setelah tujuan tercapai. Sehingga peserta didik terkadang enggan memberikan sikap positifnya lagi dalam menerima materi. Untuk itu jika pendidik dapat lebih peka dan secara kontinyu memberikan penghargaan maka peserta didik juga dapat memberi respon baik lagi. Juga peserta didik dapat termotivasi secara terus-menerus untuk mengikuti materi yang diberikan pendidik. Sebagaimana yang diungkapkan Desmita dalam Psikologi perkembangan peserta didik, bahwa setiap peserta memiliki kebutuhan akan penghargaan untuk membuktikan pada lingkungannya bahwa dirinya juga pantas untuk diakui. Mereka memerlukan penghargaan ini untuk menunjukkan eksistensi dirinya. ${ }^{24}$

Demikian pula diperlukan kesediaan pendidik dalam bersikap terbuka dalam upaya penyampaian materi atau informasi dalam kelas. Sikap ini merupakan faktor penting untuk menjalin komunikasi yang baik antara pendidik dengan peserta didik. Ini dapat diwujudkan dengan pendidik senantiasa bersikap terbuka terhadap respon peserta

\footnotetext{
${ }^{24}$ Haditiya Saputra, "Studi Tentang Kemampuan Berkomunikasi Guru dalam Meningkatkan Motivasi Belajar Siswa pada Kegiatan Belajar Mengajar di SDN 017 Kota Samarinda”, e-journal Ilmu Komunikasi, tahun 2013, 1 (1), hlm. 290-300, diakses 05 Desember 2019.
} 
didik atau pendapatnya. Tentunya peserta didik akan punya rasa bangga tersendiri ketika pendapatnya mendapat penghargaan dari pendidiknya. Sikap saling terbuka dan menghargai ini akan memperlancar arus komunikasi dan menciptakan hubungan yang baik antara kedua belah pihak. Sebab peserta merasa percaya diri karena dapat bebas menunjukkan apa yang dirinya rasakan dalam dirinya tanpa ada tekanantekanan dari pendidiknya. ${ }^{25}$

Dengan demikian, membangun komunikasi edukatif antara pendidik dan peserta didik merupakan tanggungjawab dan tugas pendidik yang sangat luas. Namun tugas memberikan informasi atau materi kepada peserta didik dalam kelas merupakan salah satu tugas penting. Begitu penting sebab berhasil atau tidaknya seorang pendidik dapat diukur dari aspek ini. Salah satu terwujudnya komunikasi yang baik ialah terciptanya kondisi kelas yang kondusif. Di sini pendidik yang menjadi kunci untuk memegang kendali atas peserta didik. Penciptaan kondisi kelas ini memudahkan komunikasi terjalin dengan baik tanpa ada gangguan. Pengendalian ini dimaksudkan agar peserta didik dapat senantiasa fokus pada proses penyampaian informasi atau berita sehingga tidak ada celah yang dapat memutuskan komunikasi antara pendidik dan peserta didik.

\section{Kesimpulan}

Pendidik dan peserta didik merupakan komponen yang penting untuk mensukseskan komunikasi dalam lembaga pendidikan. Komunikasi dalam lingkungan belajar masih sangat penting untuk dilakukan baik verbal maupun nonverbal. Oleh karenanya baik pendidik maupun peserta didik sebisa mungkin harus memiliki kualifikasi yang sudah dipaparkan diatas. Jika pendidik sebagai pemantik dalam proses komunikasi mampu menyampaikan pesan kepada peserta didik dengan baik maka akan tercipta suasana belajar yang kondusif serta komunikasi efektif.

Selain itu komunikasi ini menjadi penting khususnya dalam pendidikan Islam, sebab seperti sudah dijelaskan bahwa Islam tidak secara sederhana memandang komunikasi. Komunikasi dalam pendidikan Islam tidak hanya sebatas proses interaksi namun juga memuat kandungan filosofis yang lebih mendalam. Sehingga komunikasi pendidik dan peserta didik dalam pendidikan Islam ini lebih edukatif ketimbang komunikasi biasa yang terkadang tidak memandang sisi filosofis.

Komunikasi yang akan diwujudkan antara pendidik atau guru dan anak atau peserta didik harus berjalan dengan baik. Komunikasi ini menjadi penentu bagaimana peserta didik mampu menerima dan mengolah informasi yang dia peroleh. Pendidik harus mempunyai kemampuan komunikasi yang baik agar tersampaikan informasi kepada peserta didik. Inovasi baru perlu diwujudkan untuk membuat peserta didik merasa nyaman dalam menerima informasi atau pesan. Penyampaian materi ini

\footnotetext{
${ }^{25}$ Ibid., hlm. 297.
} 
memerlukan situasi yang kondusif sehingga peserta didik dapat dengan mudah menyerap materi. Untuk itu pendidik harus membuat konsep belajar yang memungkinkan peserta didik tidak jenuh. Dengan suasana yang lebih kondusif maka akan tercipta kondisi emosional yang menyenangkan tiap peserta didik. Motivasi belajar yang menyenangkan juga baik untuk disampaikan agar peserta didik dapat belajar dengan menyenangkan.

\section{Daftar Pustaka}

Abdul Mujib dan Jusuf Mudzakir, Nuansa-Nuansa Psikologi Islam, Jakarta: PT Raja Grafindo Persada, , 2001.

Basuki \& MiftahulUlum, Pengantar Ilmu Pendidikan Islam, Ponorogo: STAIN PO Pres, 2007.

Brantas. Dasar - dasar Manajemen, Bandung: Alfabeta, 2009.

E. Mulyasa, Menjadi Guru Profesional Menciptakan Pembelajaran Kreatif dan Menyenangkan, Bandung: PT. Rosyda Karya, 2007.

Haditiya Saputra, "Studi Tentang Kemampuan Berkomunikasi Guru dalam Meningkatkan Motivasi Belajar Siswa pada Kegiatan Belajar Mengajar di SDN 017 Kota Samarinda", e-journal Ilmu Komunikasi, tahun 2013, 1 (1), hlm. 290300, diakses 05 Desember 2019.

Kunandar, Guru Profesional, Jakarta: PT Raja Grafindo Persada, 2007.

Muhammad Arni, Komunikasi Organisasi, Cet 8, Jakarta: Bumi Aksara, 2007.

Muhammad Nurdin, Kiat Menjadi Guru Profesional, Jogjakarta: Ar-Ruzz Media, 2007.

Ngainun Naim. Dasar-dasar Komunikasi Pendidikan, Yogyakarta: ArRuzz Medi, 2011.

Pawit M. Yusuf, Komunikasi Instruksional, Teori dan Praktik, Jakarta: Bumi Aksara, 2010.

Purwadarminto, Kamus umum Bahasa Indonesia, Jakarta: Balai Pustaka, 1991.

Siti Aminah, "Membangun Komunikasi Efektif antara Pendidik dengan Peserta Didik dalam Perspektif Islam", Madrasah, Vol. 5, No.2, Januari-Juni 2013.

Suranto AW, Komunikasi Perkantoran (Prinsip Komunikasi Untuk Meningkatkan Kinerja Karyawan)., Yogyakarta: Media Wacana, 2005.

Suryosubroto B., Proses Belajar Mengajar Di Sekolah. Jakarta: PT Rineka Cipta, 2002. Syaiful Bahri Djamarah, Guru dan Anak Didik dalam Interaksi Edukatif. Jakarta: PT Rineka Cipta, 2005.

Thoha Miftah, Perilaku Organisasi Konsep Dasar dan Aplikasinya, Jakarta: Raja Grafindo Persada, 2009.

Triyo Supriyatno, Paradigma Pendidikan Islam Berbasis Teo - Antropo Sosiosentris, Malang: Universitas Islam Negeri Malang, 2004.

Wexley N., Kenneth \& Gary A. Yuki diterjemahkan oleh Muh. Shobaruddin, Perilaku Organisasi dan Psikologi Personalia, Jakarta: PT Rineka Cipta, 2003.

Zakiah Deradjat, Metodik Khusus Pengajaran Agama Islam, Jakarta: Bumi Aksara, 2004. 